\title{
"...What of the Night?" Theology of Night in the Book of Job and the Psalter
}

\author{
Funlola OloJede (US)
}

\begin{abstract}
A textual overview of the book of Job and of the Psalter shows an existential correlation between night and darkness that is naturally characterised by terror, horror, agony, oppression, pain, evil and wicked activities. However, the night, a symbol of uncertainty and fear is also portrayed as a time of revelation, of fellowship, and of divine activities, which neutralises in a sense the seeming polarity and tension between night and day, between nocturnality and diurnality. The theological analysis of the night in both the book of Job and the Psalter shows Yahweh as absolutely in control of the temporal order and it is argued that this has strong implications for wisdom theology in particular and for the theology of the $H B$ as a whole.
\end{abstract}

Key words: Night, Job, Psalter, darkness

"The morning cometh, and also the night: If ye will inquire, inquire ye..." (Isa 21:12)

\section{A INTRODUCTION}

To begin, any thorough discussion of night in the (Hebrew) Bible needs to take into account or take its point of departure from the concept of time given that night is a unit of time. Specifically, night is the unit of time which refers to the period of darkness between sundown and sunrise. ${ }^{1}$ It begins in the evening at twilight and ends at dawn. By nature, events and human experiences are interwoven with time, which implies that the temporal setting of an event or experience is important and integral to the event. In other words, events and occasions are time-bound or distinguished by time. Brin remarks that, "The determination of the time when a given event or action took place is extremely

* Article submitted: 10 October 2015; accepted: 30 October 2015. To cite: Funlola Olojede, “"...What of the Night?' Theology of Night in the Book of Job and the Psalter," Old Testament Essays (New Series) 28 no. 3: 724-737. DOI: http:// dx.doi.org /10.17159/2312-3621/2015/v28n3a10

1 Pfeiffer et al identify a basic division of time into day, hour, week, month and year. Night, like morning, dawn, midday, moment, noon, etc., is considered an expression of time. See Charles F. Pfeiffer, Howard F. Vos and John Rea eds., Wycliffe Bible Encyclopedia (Chicago: Moody Press, 1976), 1710-1711. 
important for understanding the situation described."2 Because night is a unit of time, the activities and experiences that occur at night are worth investigating. From a theological viewpoint, it is crucial to probe the significance of the experiences and events associated with night in the (Hebrew) Bible.

Even though a number of studies have been done on the concept of time in the Bible, very little has been said about night as a unit of time besides a few scattered entries in some encyclopedias and dictionaries. This is remarkable considering that night has existed from the beginning of creation and it is a natural phenomenon. Therefore, the question posed to the watchman in Isa 21:11, "Watchman, what of the night?" can be appropriated in a volume like this which is centred on nature and natural phenomenon. Since the watchman's answer is, "If you would like to enquire about night, go ahead," this paper probes the theology of the concept of night in the OT, specifically in the book of Job and in the Psalter.

Although the Hebrew word לִיְ⿱ occurs more than 250 times in at least 32 of the 39 books of the OT, its frequency of occurrence in the book of Job (21 times) and the Psalter (31 times) is only paralleled by that of Genesis (30 times). A thorough study of the theological relevance of the phenomenon of night in the whole of the OT would certainly turn out to be an unrealistic goal in a short article of this nature hence the delimitation of the subject matter to the book of Job and the Psalter. However, this initial attempt could open up the investigation of the concept in other books of the OT and in the Bible as a whole. To begin, the book of Job has much in common with the Psalter especially when it comes to the question of form and genre. Like most of Job which is only interspersed with narratives, the Psalms are poetry. Whereas the unit of Job 1-2 is regarded as the book's prologue and ch. 42:7-17 is classified as the epilogue, both of which are in narrative prose forms, ch. 3-42:1-6 are poetic. ${ }^{3}$

2 See Gershon Brin, The Concept of Time in the Bible and in the Dead Sea Scrolls (STDJ 39; Leiden: Brill, 2001), 25.

3 Seow notes that Job is a combination of a prose framework and a poetic middle; $\mathrm{cf}$. Wolters who says, "The Book of Job is poetic throughout, and almost entirely formally poetic" i.e. the poem is "framed within a partly prose Prologue and Epilogue." Whybray explains that the body of the book is in poetical form primarily because poetry is more suitable for the expression of complex emotional scenes than prose. See C. Leong Seow, Job 1-21: Interpretation and Commentary (Illuminations; Grand Rapids, Mich.: Eerdmans, 2013), 27; David Wolters, Deep Things out of Darkness: A Book of Job: Essays and a New Translation (Grand Rapids, Mich.: William B Eerdmans, 1995), 22, 67; Norman Whybray, Job (Readings; Sheffield: Sheffield Phoenix Press, 2008), 3. The Psalter is also composed notably as poetry. See Nancy L. deClaissé-Walford, "The Theology of the Imprecatory Psalms," in Soundings in the Theology of the Psalms (ed. Rolf A. Jacobson; Minneapolis, Minn.: Fortress, 2011), 
The poetry of the Psalms is said to appreciate the beauty of nature and the God of nature. Both the Psalter and Job also contain numerous images of nature and natural phenomenon. Fyall observes that, "The imagery of nature in Job is part of the Bible's presentation of creation which is at the heart of the biblical story." He further shows that the "Image of nature occurs widely throughout the book," that is, animal, botanical, cosmological images, among others. Eaton confirms that the Psalms also offer perspectives on creation and the animal world, among other things. ${ }^{4}$

Furthermore, the book of Job is ascribed to the genre of Wisdom Literature just as a number of Psalms are regarded as wisdom Psalms. ${ }^{5}$ In terms of content, some aspects of Job's speeches also bear striking resemblance to some Psalms of lament. On a thematic level, the key theological theme in the Psalter is the focus on God or the God-centredness just as in the book of Job in which Job wonders where God is in his whole predicament. ${ }^{6}$ Following the Vulgate, most modern versions of the Bible place Job before the Psalms even though in some Hebrew editions, the reverse is the case and a few others place it after Proverbs in the canonical arrangement. It is therefore also reasonable to examine the concept of night in the two books based on their proximity in the canonical order. No doubt, both books also diverge in several points especially in the fact that the Psalter unlike Job was (and still is) essentially a liturgical literature used in cultic settings.

Again, it is important that a theological discussion of night in the OT traces its origins to the creation story in Gen 1 where God separated the light

90; John Goldingay, Psalms 1-41 (vol. 1 of Psalms; BaCOT; Grand Rapids, Mich: Baker Academic, 2009), 37-42.

4 Robert S. Fyall, Now My Eyes Have Seen You: Images of Creation and Evil in the Book of Job (NSBT; Downers Grove, Ill.: InterVarsity, 2005), 57; See John Eaton, The Psalms: A Historical and Spiritual Commentary with an Introduction and New Translation (London: T \& T Clark, 2003), 3; cf. also James A. Loader, "Seeing God with Natural Eyes: On Job and Nature," OTE 5 (1992): 350-357. It is interesting that of the diverse natural phenomena (including darkness and light) which Loader has identified in the book of Job, units of time such as night and day are missing.

5 Anderson classifies Pss 36; 37; 49:1-14; 73; 78; 110; 112; 127; 128 and 133 as wisdom Psalms with Pss 37; 49 and 73 exhibiting stronger features of wisdom. But he acknowledges that, "There is much difference of opinion about the criteria for determining wisdom psalms and about the number of psalms that should be included in this category." See Bernhard W. Anderson, Out of the Depths: The Psalms Speak for Us Today (Philadelphia, Pa.: Westminster Press, 1983), 216-217. Cf. Nancy L. deClaissé-Walford, Reading from the Beginning: The Shaping of the Hebrew Psalter (Macon, Ga.: Mercer University Press, 1997), 41-42.

6 Geoffrey W. Grogan, Psalms (THOTC; Grand Rapids, Mich: Eerdmans, 2008), 231-232; cf. Loader, "Seeing God,” 346-360. 
from the darkness and called the one, day, and the other, night. We now turn to this in the next section.

\section{B NIGHT IN RELATION TO DAY AND TO DARKNESS IN THE OT}

Day and night often form a word pair in the OT just as light and darkness, and whereas night is naturally identified with darkness day is associated with light. ${ }^{7}$ In Gen 1:3, God created the light and proceeded to separate the light from the

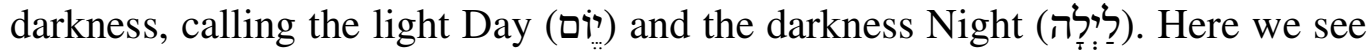
that God himself was the first to establish a correspondence between night and darkness and between day and light, and to use these to organise time. In Gen $1: 4$, he called the light good but did not say the same of darkness. Westermann argues that God was in essence expressing "prejudice" towards light. ${ }^{8}$ However, this may not necessarily be the case. God said the light was good because it was the first of his creative acts and he would subsequently comment on all other elements of his creation in the same manner. In contrast, darkness was not part of that creation; it existed before and predated the creation in Gen 1.' The origin of night in creation in the OT therefore places it squarely within creation theology. In this sense, both Job and the Psalter are identified understandably with creation theology. ${ }^{10}$

As a word pair, "day and night" is used figuratively in the OT (and in common parlance) to express a continuous or perpetual process. It is used to mark something that takes place around the clock or non-stop (e.g. Lev 8:35; Josh 1:8; 2 Chr 6:20; Neh 1:6; Jer 9:1; Lam 2:18). The negative variant, day nor night also expresses continuity (e.g. Eccl 8:16; Isa 60:1; 62:6) but on its own, day is used as the most basic unit of time which also includes the night hours. Thus, in the OT world, the temporal order of the day (in the sense of a 24-hour period) is morning to night although there have been insinuations that the reverse could also be the case. The preponderance of evidence however

7 See Brin, Concept of Time, 155.

8 Pfeiffer et al confirm that in the Bible, God is revealed as creating and acting in time (Pfeiffer et al, Wycliffe Bible Encyclopedia, 1708). Claus Westermann, Genesis: A Practical Commentary (trans. D. E. Green; Grand Rapids, Mich.: WmB Eerdmans, 1986), 8.

9 We should note however, that Isa 45:7 states that God formed both light and darkness. Perhaps then, darkness was created in another act that predated Gen 1.

${ }^{10}$ Fyall links the book of Job with creation and a major theme in the Psalms is the depiction of Yahweh as the God of creation (Fyall, Now My Eyes, 57-100, 117-174; see also Grogan, Psalms, 246-250; Hulisani Ramatswana, "Conflicts at Creation: Genesis 1-3 in Dialogue with the Psalter," OTE 27 (2014/2): 553-578. In the same vein, Perdue has argued that wisdom literature is grounded in the theological tradition of creation. Leo G. Perdue, Wisdom and Creation: The Theology of Wisdom Literature (Nashville, Tenn.: Abingdon, 1994), 191-192. 
indicates that the ancient Israelites measured the day from morning to night and not the other way round. ${ }^{11}$ In the order of time in nature, the day is said to precede the night.

In the ancient Hebrew world, the night was divided into three watches namely the evening or the first watch (also called the beginning of the watches), the middle watch and the morning watch, approximately and respectively from sunset to 10.00 P.M.; from 10.00 P.M. to 2.00 A.M.; and from 2.00 A.M. to sunrise. The NT taking a cue from the Roman division of time divides the night into four watches namely evening, midnight, cockcrowing and morning. ${ }^{12}$ Within these divisions of the night, some people could set or post a watch during the night watch (Judg 7:19; Pss 90:4; 119:148), and those who did so were called watchers or watchmen (cf. Ezek 33:7). However, this is not to say that watches were not set in the daytime. For instance, in situations of war, or when there was a threat from the camp of the enemy, a day watch could be posted as Neh 4:21 shows; and watchers could operate around the clock if the situation demanded it.

Given that darkness is naturally associated with night, it is important to note that night is sometimes used metaphorically to refer to a time of crisis, of distress, of helplessness or of God's judgement (cf. Isa 15:1; 21:11-12; Mic $3: 6)$. It also appears that the association of fear and dread with nighttime is in a sense a universal phenomenon that cuts across the boundaries of culture. Brin confirms that, "There is a natural association between fear and nighttime that imposes fear through its darkness, more so than it would be connected associatively with daytime." ${ }^{\prime \prime}$ In Africa for instance, one strong reason the night is associated with evil is the belief that witchcraft operations and caucuses take

11 See Cassuto who also points out that the Torah commanded that the observation of some festivals and appointed times should begin on the night of the preceding day, e.g. eating the Unleavened Bread on the night of the Passover and fasting on the evening before the Day of Atonement. Umberto Cassuto, From Adam to Noah: Genesis i-vii (vol. 1 of A Commentary on Genesis; trans. I. Abrahams; Jerusalem: The Magnes Press, The Hebrew University, 1961), 29. Brin argues that, "An examination of the normal order of time in the Bible indicates, in my opinion, an approach to the day that begins with the morning and concludes at night . . . This follows clearly from such verses as Exod 24:18; 34:28; $1 \mathrm{Kgs}$ 19:8: 'forty days and forty nights' . . . We clearly see that in elucidating the order of the day, the day precedes the night" (Brin, Concept of Time, 158, cf. 155-156; 1 Sam 30:12; Jonah 2:1; Job 2:13; 3:3; Isa 21:12). However, he concedes that in some instances, the night is placed before the day, that is, "the night is used as the starting point for specific reasons related to the text in question, and not because of some ideology concerning a different system of counting" (Brin, Concept of Time, 162). Among others, examples include Deut 1:32; 28:60; 1 Sam 25:16; 1 Kgs 8:29; Ps 91:5; and Prov 3:24.

12 Pfeiffer et al, Wycliffe Bible Encyclopedia, 1787, 1711.

13 Brin, Concept of Time, 159. 
place primarily at night. It is assumed that in the spiritual realm, forces and agents of witchcraft prey on their victims in the hours of darkness. Enchanters, diviners, astrologers, occultists, necromancers, and various subterranean forces test their craft and target their victims and opponents at night. Such beliefs are widespread across Africa. ${ }^{14}$

However, in Africa, the fear of nighttime is not restricted to spiritual activities. I recall a poignant poem written by Oswald Mtshali in the dark days of apartheid in South Africa titled "Nightfall in Soweto." 15 Mtshali graphically described the terror and horror that accompanied nighttime in the Soweto of the apartheid era; a terror inflicted by human agents of darkness - the apartheid police. The poem captures the emotion of fear that is naturally linked with night because of its darkness which in essence typifies mystery, hiddenness or the unknown. Like Job (Job 7:4), Mtshali dreaded the night; he wished night was never created and that time would be frozen into one long day. His comparison of night to "a dreaded disease" also seems to echo Job's view of night as a tormentor that pierced his bones (Job 30:17). Again, in crime prone contexts, there is a natural dread of nighttime because of the activities of men of the underworld such as robbers, burglars, rapists, murderers and various assail-

14 Zach Kotzé, "The Witch in Psalm 59: An Afrocentric Interpretation," OTE 21/2 (2008): 385.

15 Nightfall comes like a dreaded disease seeping through the pores of a healthy body and ravaging it beyond repair

A murderer's hand, lurking in the shadows, clasping the dagger, strikes down the helpless victim. Where I barricade myself against nightfall.

I am the victim.

I am slaughtered every night in the streets. I am cornered by the fear gnawing at my timid heart; in my helplessness I languish.

Man has ceased to be man Man has become beast Man has become prey. Where is my refuge? Where am I safe? Not in my matchbox house

I am the prey; I am the quarry to be run down by the marauding beast

let loose by cruel nightfall from his cage of death. I tremble at his crunching footsteps, "Open up!" he barks like a rabid dog thirsty for my blood.

\author{
Nightfall! Nightfall! \\ You are my mortal enemy. \\ But why were you ever created? \\ Why can't it be daytime? \\ Daytime forever more?
}

See Oswald M. J. Mtshali, "Nightfall in Soweto," in A Selection of African Poetry (ed. Kojo E. Senanu and Theo Vincent; Essex: Longman, 1988), 257. 
ants who operate under the cover of darkness. Similarly, the OT is replete with negative images relating night to darkness and to fear. Without doubt, darkness which belonged to the elements of chaos at the time of creation lends its power to the night so that it becomes scary. But the question is, is nighttime solely a time of dread, of anxiety and of uncertainty? Let us consider the book of Job and the Psalms for some clues.

\section{NIGHT IN JOB AND PSALMS - BACKGROUND}

The book of Job recounts the suffering and agony experienced by one man Job, whose friends, using conventional wisdom, tried to persuade him that his situation was the consequence of some misdeeds in his past. Job rejected their rationalisation of his sufferings, questioned God's judgement, and insisted that he was an innocent victim of circumstances. The bulk of the book (i.e. chs. 341 ) is composed of different dialogues between Job and his three friends and lengthy monologues which Job addressed to a God who was no longer within his radar. In Job, the hiddenness of God is glaring as he vanished from the scene after orchestrating and stage-managing Job's ordeal. The darkness that engulfed Job was compounded by that mysterious absence of God in the subsequent stages of the agonising drama of his life. Even as his friends' words tormented and taunted him, and his complaints turned bitter and heart wrenching, God refused to show up. Where is God in the midst of the darkness and of the horrors of the night? In the sense of its inscrutability, the idea of theodicy ${ }^{16}$ which is a central theme in Job seems to correspond strongly with the mystery of darkness and of night embodied in the narrative of Job. To Job, his experience was a nightmare, and the darkness in his soul would simply not go away until the very end when the hidden God surfaced out of the whirlwind.

The book of Job therefore served as a kind of polemic against the conventional wisdom that was prevalent at the time of Job which determined that whatever one sows, one would also reap. It shows that indeed the innocent can suffer and experience shadows even at noontime. Job himself and not the wicked was the man who "met with darkness in the daytime and groped in the noonday as in the night" (Job 5:14). His story was not by any chance a tale by the moonlight for Job's night was starless, moonless, and dreadfully long. It was a story that was most difficult to tell. Day unto day for seven days, none of his three friends uttered any speech, and night unto night for seven nights no one could display any knowledge. The only sound in sight was of sighing, of sorrow, of silence. The darkness around Job was a darkness that could be touched, a darkness that could be seen, a darkness too heavy to describe. But in the end, his experience showed that indeed after the darkness of night comes the light of dawn.

16 The book of Job is said to be "unquestionably a theodicy, an essay in the justification of the ways of God to man" (Wolters, Deep Things, 68). 
The book of Job is composed as a single narrative couched in poetry and speeches uttered by human characters in the persons of Job, his wife and his four friends as well as by spiritual beings in the persons of Satan and God. The bulk of the book is composed of disputations between Job and his friends. On the other hand, the book of Psalms is variegated in content and theme, and the identities of its composers and singers remain largely uncertain. Thus, it is not an exaggeration to say that the Psalms are difficult to classify especially because many of the themes and the forms overlap with one another. In terms of structure, most scholars readily classify the Psalter into five books but the lines of demarcation generally vary. ${ }^{17}$ Based on content however, Psalms are organised into royal psalms, wisdom psalms, lament psalms, messianic psalms, Torah psalms, among others, while based on form, they are identified as alphabetic acrostic psalms, hymnic psalms, etcetera, all of which are addressed to God. ${ }^{18}$ Lament psalms are categorised into two - personal or individual and communal or community laments. Personal laments express the emotions and anguish of an individual in distress while communal laments represent the petitions of the whole community in a time of crisis or opposition. ${ }^{19}$

Noteworthy however is Brueggemann's arrangement of the Psalms into Psalms of orientation, Psalms of disorientation and Psalms of new orientation corresponding respectively to seasons of wellbeing, "anguished seasons of hurt, alienation, suffering and death," and surprise "when joy breaks through despair." ${ }^{20}$ The Psalms of disorientation (Pss 13, 32, 35, 49, 50, 51, 73, 74, 79, 81, $86,88,90,109,130$ and 143) are said to include personal and communal laments which Brueggemann calls "psalms of darkness." He writes that, "For that speech of disorientation, I take the personal lament psalm to be the clearest and most simple example." ${ }^{21}$ The fact that the psalms of disorientation which

17 Compare the classification of the Psalms by Anderson, Out of the Depths, 239242; De-Claissé-Walford, Reading, 48, 33-35; Grogan, Psalms, 21-28, 42; Goldingay, Psalms, 23.

18 See Anderson, Out of the Depths, 216-223; De-Claissé-Walford, Reading, 41-43.

19 Walter Brueggemann, The Message of the Psalms (AOTS; Minneapolis, Minn.: Augsburg Publishing House, 1984), 58-67. Anderson notes that communal laments "were used on fast days when the community was threatened by military foes, famine, drought, or some pestilence such as a locust plague (cf. The Book of Joel)" but in individual laments, it is not often certain what the trouble was. In both forms however, enemies have a central place Anderson, Out of the Depths, 82-83.

20 See Brueggemann, Message, 25-167. Examples of Psalms of orientation are Pss 1, 8, 14, 15, 24, 33, 37, 104, 112, 131, 133 and 145, while Psalms of new orientation include Pss 23, 27, 29, 30, 34, 38, 40, 47, 65, 66, 91, 93, 96, 97, 98, 99, 100, 103, 113, $114,117,124,135,138$, and 146-150. Note also Anderson's list of individual and community laments and the point that the line between the two forms of lament is sometimes blurred. Anderson, Out of the Depths, 70-75.

21 Brueggemann, Message, 52, 58. 
find expression in laments are connected with darkness is striking. It has also been observed that, "The lament is widely attested in the book of Job; in fact, it dominates the book." 22 Perhaps this common feature is due to the experience of suffering which is expressed widely in the Psalter but is also at the heart of the story of Job. ${ }^{23}$ The question of theodicy also surfaces in the lament Psalms as the psalmist wondered why the innocent suffered but the wicked continued to prosper (cf. Ps 73). Suffering clearly gives birth to lament and darkness, while night metaphorically captures the time and peak of suffering.

In what follows therefore, we shall consider nighttime in the world of Job and of the Psalter. Do both books share common images of night; or do the images depart from each other? A textual appraisal of the two books in terms of the nighttime activities and the actors could offer some theological insight into their depictions of night. As would be expected, it is not easy to determine the criteria for classifying the expressions of night in the two books primarily because of the diverse character of the material and some other exegetes may choose to approach them differently.

\section{EXPRESSIONS OF NIGHT IN JOB AND THE PSALTER}

In both the Psalter and the book of Job, we find various personal musings about night. This is perhaps due to the nature of the content of the two books which is predominantly in direct speech. Most of the hints about night are expressed in direct speech and they constitute mainly the reflections of the speakers on night as well as their experiences in the night, or the nighttime activities. However, the two books present voices by different characters which at times are in harmony and at other points in dissonance with one another. A few observations about the textual data on night are in order at this point. First, in the Psalms, day and night are used as a fixed pair five times (Pss 1:2; 32:4; 42:3; 55:10;

22 Claus Westermann, "The Literary Genre of the Book of Job," in Sitting with Job: Selected Studies on the Book of Job (ed. Roy B Zuck; Grand Rapids, Mich: Baker Book House, 1992), 53. For Westermann, "Job remains the lamenter" as the lament is the chief component of Job's personal arguments (Westermann, "Literary Genre," 60, 62, italics his). Hartley also shows that the lament is one of the multiple genres in the book of Job which include lawsuit, petition, hymnic lines in praise of God, wisdom instruction, and so forth. John E. Hartley, "The Genres and Message of the Book of Job," in Sitting with Job: Selected Studies on the Book of Job (ed. Roy B. Zuck; Grand Rapids, Mich.: Baker Book House, 1992), 68-69. However, Masenya (ngwan'a Mphahele) faults what she regards as the misogynist character of Job's lament in Job 3; Madipoane Masenya (ngwan'a Mphahele), "Her Appropriation of Job's Lament? Her-Lament of Job 3, from an African Story-Telling Perspective," in Postcolonial Perspectives in African Biblical Interpretation (ed. Musa W. Dube, Andrew M. Mbuvi and Dora Mbuwayesango; SBLGPBS 13; Atlanta: SBL, 2012), 283-297.

23 According to Grogan, the Psalter presents a realistic doctrine of suffering as "Many psalms reveal the sufferings of the writers" (Grogan, Psalms, 335-341). 
88:1) but they are also used together in context at least eight times (Pss 22:2; $42: 8 ; 74: 16 ; 78: 14 ; 91: 5 ; 121: 6 ; 136: 8-9 ; 139: 12)$ while night is in some cases mentioned in parallel to morning (Pss 30:5; 92:2). ${ }^{24}$ In Job on the other hand, day and night as a word pair occurs only once (Job 26:10) but night occurs in the context of day(time) or light a number of times (Job 3:3, 6, 7-8; 5:14; 7:4; $17: 12 ; 24: 14)$. However, night is used nine times in Job without any recourse to day, morning or light (Job 4:13; 20:8; 27:20; 29:19; 30:17; 33:15; 34:25; 35:10; 36:20) and at least 11 times in the Psalms (Pss 6:6; 16:7; 17:3; 63:6; 77:2, 6; 90:4; 104:20; 105:39; 119:55, 148; 134:1).

Second, of its 23 instances in Job, the word night occurs in the narrative part of Job once $(2: 13)$ and in the speeches of Zophar once (20:8), of Eliphaz twice $(4: 13 ; 5: 14)$, of Elihu five times $(33: 15 ; 34: 20,25 ; 35: 10 ; 36: 20)$, and in Job's laments 12 times $(3: 3,6,7 ; 7: 3,4 ; 17: 12 ; 24: 7,14 ; 26: 10 ; 27: 20 ; 29: 19$; 30:17). The remaining two instances occur in God's response to Job (39:9, 28 RSV). Notably, Elihu's mention of night is essentially in relation to God's nighttime activities, and his use of positive images of the night could be a subtle way of softening the dark images expressed by his friend Job in the complaints. It is remarkable also that about half of the occurrences of night in the Psalter are in the psalms of lament (see Anderson's classification). ${ }^{25}$

Third, there is not always a clear-cut break between the night and the day for the distinction is sometimes fuzzy as night dissolves into day and day into night (Ps 139:11; Job 5:14; 17:12; cf.10:22). For instance, Job 17:12 says, "They change the night into day: the light is short because of darkness." And the Psalmist says in Ps 139:11, "If I say, 'Surely the darkness shall cover me;' even the night shall be light about me." As a matter of fact, both light and darkness are alike to God (Pss 74:6; 139:12; cf. Job 18:6; Isa 45:7). ${ }^{26}$ This melting or fading of night into day and day into night is seen in other parts of the OT. For instance, in Amos 5:8, the house of Israel is encouraged to seek him ... that turns the shadow of death into morning, and makes the day dark with night . .." In Josh 10:12-13, the day prevailed over the night as the sun and the moon stood still for Joshua to accomplish his goal (cf. also Jer 13:16).

24 In Ps 90:4 however, night is used in the context of yesterday.

25 Anderson, Out of the Depths, 70-77.

${ }^{26}$ Of Job 3:3, Fokkelman says, "Day and night are very much involved with each other ... So night penetrates into day and day penetrates into night ... The polarity of night and day is also that of darkness and light, and as such constitutes one of the most spectacular dualities of the universe, and of our world." See Jan P. Fokkelman, Ex. 115, Deut. 32, and Job 3 (vol. 1 of Major Poems of the Hebrew Bible at the Interface of Hermeneutics and Structural Analysis; SSN; Assen: Van Gorcum, 1998), 59. 
Fourth, nighttime activities and experiences in the two books are numerous. However, some things take place both in the day and the night. In the Psalms, these include God's punishment (Ps 32:4); God's guidance (Pss 105:39; 78:14); expression of God's חסֶד (92:2); fear (Ps 91:5); criminal activities (Ps 55:9-10); weeping (Pss 42:3; 88:1) which is more pronounced and aggravated in the night (Pss 30:5; 6:6), ${ }^{27}$ or crying out to God (Ps 22:2), and meditation on the word (Ps 1:2 [119:148]). In Job, activities and experiences that are common to both day and night include also criminal activities (Job 24:14); anxieties (Job 7:4); confusion of the cunning and the wicked (Job 5:14); and destruction of the wicked (Job 34:25; 36:20). In both books, activities that are associated with the night alone include singing (Job 35:10; Ps 77:6); remembrance of God (Pss 63:6; 119:55); staying forcefully awake (Job 7:4; Ps 119:148); manufacturing of darkness (Ps 104:20); God's visitation (Ps 17:3); God's instruction/revelation (Job 4:13-16; 20:8; 33:14-18; 35:11 Ps 16:7) ${ }^{28}$ and the experience of pain (Job 30:17; 33:19; Ps 77:2). Job also makes reference to the night he was conceived (Job 3:3) suggesting that in his time, copulation possibly took place generally at night. ${ }^{29}$ Above all, although night is a time of rest for the weary worker and those who have borne the burden of the day (cf. Eccl 5:12), this is only implied in both books (Job 4:13; 33:15; Ps 127:2). In time of distress, the night of rest invites only sleeplessness and anxiety (Job 7:4; 30:17; Ps 6:6).

The activities noted above show that both positive and negative images are associated with the night in Job and in the Psalter. Both books also contain similar nighttime activities. In Job however, not much attempt is made to disguise the pain and anguish that darkness offers or the helplessness of its victims. One finds a frequent occurrence of dark imageries, brutally piercing in their vividness, which are used to accentuate the horrors of night such as "shadow of death/deep shadow" (Job 3:5; 10:22), "blackness" (3:5), "grave," "terror," "cloud," etc. The book contains more negative images of the night than positive, and most of the dark images of the night emanate from Job himself as he complained to a silent God (Job 3:3-10; 7:3-4; 30:17), while the few positive images in the book occur in the speeches of his friends (Job 4:12$13 ; 33: 14-19 ; 35: 10-11)$. The only positive thing that Job himself associated

27 Perhaps people find it easier to weep longer and more heavily in the night because of the solitude and quiet that the night offers. Intense and uninterrupted contemplation of one's sufferings in the night hours could elicit weeping.

28 Note that a dream/vision of the night could either be revelatory and positive or simply be a nightmare (cf. Job 4:13-16 and 33:14-19).

29 Compare Masenya (ngwan'a Mphahele), "Her Appropriation," 293. It should be noted also that Job asked for a curse on the day he was born and the night of his conception (3:3-10). So grievous was his pain that he asked for the night of his conception to be obliterated from the calendar. See Seow, Job 1-21, 323; Fokkelman, Major Poems 1, 163. 
with the night occurred "in the months past" when his glory was still fresh in him; his root was spread out by the waters and the dew lay all night upon his branch $(29: 2 ; 19-20)$. Otherwise, to Job, the night was unbearably long (Job $7: 4)$. In the Psalms on the other hand, although the night is associated with terror (Ps 91:5), the horrors of the night are more often tempered by images of hope and of the dawn (cf. Pss 30:5; 42:3-8; 77:2, 6-12). The Psalmist expressed his personal distress and emotions in the night as well as his experiences of the night to God, but though his helplessness is real, he does not lose sight of hope and of daytime.

Lastly, besides the nighttime activities, nighttime actors in Job and the Psalter include God (Job 33:14; 34:14-15, 25; 35:10), the righteous (Pss 22:2; 42:3), the wicked (Job 24:14; Ps 63:9-10), and spirits (Job 4:15-21). Ironically, night itself is personified as a nighttime actor and Job's tormentor in Job 30:17. Job was a victim of the night which pierced his bones. But animals, birds and other elements of nature such as the dew, whirlwind, firmament, moon and stars also constitute non-human actors while terror is personified as an agent of fear (Ps 91:5). At night therefore, the animals and birds are free to roam the forests (Job 39:9, 28; Ps 104:20) as the heavens reveal the glory of the Lord (Ps 19:1-2). The moon and the stars which are rulers of nightlife engage in YHWH's praise (Pss 136:9; 148:3), and YHWH restrains the moon from unleashing any terror on the righteous (Ps 121:6). A tempest carries the rich away (Job 27:20) but the dew covers Job's branch all night long (Job 29:19). Darkness also could be a covering, the Psalmist believes, but he concludes that the light of the night is a better blanket (Ps 139:11). Thus, nighttime activities in the two books are carried out by human and spirit beings as well as non-human beings and elements. The elements specifically the moon and the stars which illuminate the night sky appear to serve as a backdrop of light for the night stage, offering a glimpse of the silhouettes of the human and spiritual actors (Job 22:12; Ps 8:3). However, in night's tragic scenes, the darkness painfully deepens as the curtains close and the lights fade out - the moon and stars no longer shine (Job $3: 9 ; 9: 7 ; 25: 5)$.

\section{E CONCLUSION}

A side-by-side reading of night in Job and the Psalter reveals that even though the wicked take advantage of the darkness of the night to engage in criminal activities and to cause the righteous pain, they have it rough with God. God also chooses the night as the time to confuse and cut them off. He inflicts punishment and judgment in the night. And on a positive note, the night is a time for a vertical communion between the righteous and God. At night, God gives songs (Job 35:10); speaks to instruct and to warn (Job 33:14-15); gives counsel (Ps 16:7); visits the righteous (Ps 17:3) while the righteous prays/seeks God (Pss 22:2; 42:8; 77:2; 88:1), meditates on God's word and sings to God (Ps 77:6), among other things. The brief investigation of the concept of night in Job 
and the Psalms also shows that God is supremely and solidly in control not only of the night but also of its activities and actors. The Psalmist recognises this fact when he says to him, "The day is yours, the night also is yours ..." (Ps 74:16). This observation tallies with the view mentioned earlier that the theological focus in both the Psalter and Job is God. Both books show clearly that God is the main actor in the night as all the other actors (human and nonhuman) defer to him. The positive activities of the righteous as well as God's benevolence in the night therefore diffuse the tension and negativity which are naturally associated with nighttime. And in a sense the seeming polarity and tension between night and day, between nocturnality and diurnality are neutralised. The night of terror and dread is demystified in those moments when the divine and the human commune. The power of darkness is subdued and order is maintained in the cosmos, as in the beginning. Untainted by horrors, the sublime beauty of nighttime illuminated by the moon and the stars in the distant sky tames the viciousness of the night. Darkness is exposed as day dawns again and the heavens declare the glory of the Lord!

\section{BIBLIOGRAPHY}

Anderson, Bernhard W. Out of the Depths: The Psalms Speak for Us Today. Philadelphia, Pa.: Westminster Press, 1983.

Brin, Gershon. The Concept of Time in the Bible and in the Dead Sea Scrolls. Studies in the Texts of the Deserts of Judah 39. Leiden: Brill, 2001.

Brueggemann, Walter. The Message of the Psalms. Augsburg Old Testament Studies. Minneapolis, Minn.: Augsburg Publishing House, 1984.

Cassuto, Umberto. From Adam to Noah: Genesis i-vii. Volume 1 of A Commentary on Genesis. Translated from the Hebrew by I. Abrahams. Jerusalem: The Magnes Press, The Hebrew University, 1961.

De-Claissé-Walford, Nancy L. Reading from the Beginning: The Shaping of the Hebrew Psalter. Macon, Ga.: Mercer University Press, 1997.

. "The Theology of the Imprecatory Psalms." Pages 77-92 in Soundings in the Theology of the Psalms. Edited by Rolf A. Jacobson. Minneapolis, Minn.: Fortress, 2011.

Eaton, John. The Psalms: A Historical and Spiritual Commentary with an Introduction and New Translation. London: T \& T Clark, 2003.

Fokkelman, Jan P. Ex. 115, Deut. 32, and Job 3. Volume 1 of Major Poems of the Hebrew Bible at the Interface of Hermeneutics and Structural Analysis. Studia Semitica Neerlandica. Assen: Van Gorcum, 1998.

Fyall, Robert S. Now My Eyes Have Seen You: Images of Creation and Evil in the Book of Job. New Studies in Biblical Theology. Downers Grove, Ill.: InterVarsity, 2005.

Goldingay, John. Psalms 1-41. Volume 1 of Psalms. Baker Commentary on the Old Testament. Grand Rapids, Mich: Baker Academic, 2009.

Grogan, Geoffrey W. Psalms. The Two Horizons Old Testament Commentary. Grand Rapids, Mich: Eerdmans, 2008. 
Hartley, John E. "The Genres and Message of the Book of Job." Pages 65-78 in Sitting with Job: Selected Studies on the Book of Job. Edited by Roy B. Zuck. Grand Rapids, Mich: Baker Book House, 1992.

Kotzé, Zach. "The Witch in Psalm 59: An Afrocentric Interpretation." Old Testament Essays 21/2 (2008): 383-390.

Loader, James A. "Seeing God with Natural Eyes: On Job and Nature." Old Testament Essays 5 (1992): 346-360.

Masenya (ngwan'a Mphahele), Madipoane. "Her Appropriation of Job's Lament? Her-Lament of Job 3, from an African Story-Telling Perspective." Pages 283297 in Postcolonial Perspectives in African Biblical Interpretation. Society of Biblical Literature Global Perspectives on Biblical Scholarship 13. Edited by Musa W. Dube, Andrew M. Mbuvi and Dora Mbuwayesango. Atlanta: SBL, 2012.

Mtshali, Oswald M. J. "Nightfall in Soweto." Page 257 in A Selection of African Poetry. Edited by Kojo E. Senanu and Theo Vincent. Essex: Longman, 1988.

Perdue, Leo G. Wisdom and Creation: The Theology of Wisdom Literature. Nashville, Tenn.: Abingdon, 1994.

Pfeiffer, Charles F., Howard F. Vos and John Rea (eds). Wycliffe Bible Encyclopedia. Chicago: Moody Press, 1976.

Ramatswana, Hulisani. "Conflicts at Creation: Genesis 1-3 in Dialogue with the Psalter." Old Testament Essays 27/2 (2014): 553-578.

Seow, C. Leong. Job 1-21: Interpretation and Commentary. Illuminations. Grand Rapids, Mich: Eerdmans, 2013.

Westermann, Claus. Genesis: A Practical Commentary. Text and Interpretation. Translated by D. E. Green. Grand Rapids, Mich.: WmB Eerdmans, 1986. . "The Literary Genre of the Book of Job." Pages 51-63 in Sitting with Job: Selected Studies on the Book of Job. Edited by Roy B. Zuck. Grand Rapids, Mich: Baker Book House, 1992.

Whybray, Norman. Job. Readings: A New Biblical Commentary. Sheffield: Sheffield Phoenix Press, 2008.

Wolters, David. Deep Things out of Darkness: A Book of Job. Essays and a New Translation. Grand Rapids, Mich: William B Eerdmans, 1995.

Dr. Funlola O. Olojede is a research associate at Old and New Testament, Stellenbosch University, South Africa. Email: funlola@sun.ac.za. 